Trinity University

Digital Commons @ Trinity

Philosophy Faculty Research

Philosophy Department

2007

\title{
The Scepticism of Francisco Sanchez
}

Damian Caluori

Trinity University, Damian.Caluori@trinity.edu

Follow this and additional works at: https://digitalcommons.trinity.edu/phil_faculty

Part of the Philosophy Commons

\section{Repository Citation}

Caluori, D. (2007). The scepticism of Francisco Sanchez. Archiv für Geschichte der Philosophie, 89(1), 30-46. doi:10.1515/AGPH.2007.002

This Article is brought to you for free and open access by the Philosophy Department at Digital Commons @ Trinity. It has been accepted for inclusion in Philosophy Faculty Research by an authorized administrator of Digital Commons@ Trinity. For more information, please contact jcostanz@trinity.edu. 


\title{
The Scepticism of Francisco Sanchez
}

\author{
by Damian Caluori (Oxford)
}

\begin{abstract}
The Renaissance sceptic and medical doctor Francisco Sanchez has been rather unduly neglected in scholarly work on Renaissance scepticism. In this paper I discuss his scepticism against the background of the ancient distinction between Academic and Pyrrhonian scepticism. I argue that Sanchez was a Pyrrhonist rather than, as has been claimed in recent years, a mitigated Academic sceptic. In keeping with this I shall also try to show that Sanchez was crucially influenced by the ancient medical school of empiricism, a school closely allied with Pyrrhonism.
\end{abstract}

Francisco Sanchez (1551-1623) ${ }^{1}$ has not received a lot of attention in recent scholarly discussion of Renaissance scepticism. ${ }^{2}$ Popkin, for example, in his classic History of Scepticism, devotes only six pages to him. ${ }^{3}$ In his day, however, and up to the middle of the $17^{\text {th }}$ century, Sanchez was a fairly well known sceptic. Bayle praised him in his Dictionnaire historique et critique as a "grand Pyrrhonien" and Gabriel Naudé demanded in his Advis pour dresser une bibliothèque (1627) that Sanchez's sceptical work, his Quod nihil scitur (That nothing is known) (1581), should be part of every decent library. ${ }^{4}$ As late as the seventeen sixties, some German philosophers considered Sanchez a worthwhile topic for refutation. ${ }^{5}$

1 After having studied medicine at the Collegio de la Sapienza in Rome and at the University of Montpellier, Sanchez spent most of his life as a professor of philosophy at the University of Toulouse and - at the same time - as a doctor at the town's hospital. Only late did he succeed in getting a chair at the Faculty of Medicine. Although he had written some commentaries on Aristotle and quite a number of medical treatises, his fame was exclusively based on his one sceptical work, Quod nihil scitur, and this work will be the focus of the present paper.

2 A laudable exception is the edition of Limbrick/Thomson 1988. Although I disagree with Limbrick's evaluation of Sanchez's scepticism, her substantial introduction (henceforth quoted as "Limbrick" + page number) to this edition was of great help to me.

3 Popkin ${ }^{32003,38-43 .}$

4 Naudé's Advis has been edited by Jolly. See Jolly 1990, 44-45.

5 J. U. Wildt, Quod aliquid scitur, Leipzig 1664; D. Hartnack, Sanchez aliquid sciens, Stettin 1665; G. Wedderkopf, De Scepticismo profano et sacro praecipue Remonstratium, Strassburg 1664. 
Both his admirers and his opponents agreed that Sanchez was a sceptic. But even if we know that he was, it is not clear what kind of scepticism he proposed. As is well known the ancients distinguished between two kinds of scepticism which are often called - following Sextus' Outlines of Pyrrhonism (I, 1ff.) - Pyrrhonian and Academic scepticism respectively. ${ }^{6}$ In recent years Sanchez has usually been described as an Academic sceptic. ${ }^{7}$ In the present paper I wish to re-evaluate this claim.

\section{$I$}

Let us first examine whether Sanchez's scepticism is of Academic ilk. According to Limbrick, "Sanches's scepticism is philosophically anchored in the Academic scepticism of the school of Carneades" (Limbrick 88). She provides three arguments for this claim. Firstly, Sanchez signs off a letter to Clavius, the famous Renaissance mathematician and astronomer, with "Carneades philosophus". Carneades was one of the most important proponents of Academic scepticism in antiquity and in signing off with Carneades' name, Sanchez sides, according to Limbrick, with the Academics (Limbrick 78). Secondly, in his commentary on Galen's De pulsibus ad tyrones Sanchez withholds judgment "Academicorum more" as he puts it (ibid.). ${ }^{8}$ Thirdly, referring to a passage in another commentary on Galen, Limbrick claims: "In his role as a physician, when called on to make a diagnosis of a disease, he examined the evidence and then followed what seemed more probable" (Limbrick 79). ${ }^{9}$

Let us now examine these three arguments. The first and the second rely on the assumption that in Renaissance philosophy, Academic and Pyrrhonian scepticism were clearly distinguished from one another. As Schmitt has shown, however, this is not the case. ${ }^{10}$ For Renaissance philosophers the words "sceptic", "Academic" and "Pyrrhonian" were synonymous. Limbrick herself states: "A further complication ensued in the late Renaissance when the term Académique and Pyrrhonien also came to be used interchangeably. For example, Montaigne in the 'Apologie de Raimond Sebond' makes no clear distinction between Academic scepticism and Pyrrhonian scepti-

\footnotetext{
${ }^{6}$ Scholarly debate of the difference between Academic and Pyrrhonian scepticism, a topic already hotly discussed in late antiquity, can be found, e.g., in Striker 1996a and in Burnyeat/Frede 1997.

7 Limbrick 78 ff.; Popkin ${ }^{32} 2003$, 38-43.

${ }^{8}$ In his Opera medica, Toulouse 1636, 606.

9 "Nos tamen quod probabilius videtur sectantes, dicemus ...", In librum Galeni de differentiis morborum commentarii, Opera medica, 711.

10 Schmitt 1972, 7 and 74
} 
cism" (Limbrick 67f.). But if so, then the first two arguments lose their bite. We can at most infer from them that Sanchez considered himself a sceptic but we cannot establish whether his scepticism was Academic or Pyrrhonian.

What about the third argument? True, the ancient Academic sceptics, at least from Carneades onwards, used the notion " $\pi \bullet \propto \alpha v v^{v}$ " or, as Cicero rendered it, "probabile" - a term perhaps best translated as "persuasive". ${ }^{11}$ This notion is important for the question whether a sage has opinions or views and what kind of views he can have. According to Carneades a sage sometimes has views or opinions (Cicero, Academica 2, 67). But these views have to be persuasive (Cicero, Academica 2, 104-5; Sextus Empiricus, Against the Mathematicians 7, 166-89, and Outlines I 226-31). What does it mean for a view to be persuasive? Carneades' pupils and followers were divided into two camps on this question. According to Clitomachus, a sage will hold persuasive views in the following sense. Some views or impressions will simply strike him as persuasive in such a way that he will have no qualms acting on their basis without, however, believing them to be true. But the Clitomachean view is even more radical than this. For the sage does not even believe that the views that seem to him to be persuasive are probable in any objective sense (Cicero, Academica 2, 104). Accordingly, although the sage will act on the basis of certain views and not act on the basis of others, he does not believe himself to possess reasons to prefer the former to the latter.

Metrodorus and Philo disagreed with Clitomachus' interpretation. According to them, an impression or view or opinion is persuasive only if we have better reasons to believe it than not to believe it. In this way it is possible for the sage, according to them, to justify his views or opinions. On the basis of this justification the sage believes that the truth of his views or opinions is more likely than their falsehood.

One might wonder whether this interpretation does not bring them too close to their dogmatic opponents, the Stoics. But despite their disagreement with Clitomachus, they also clearly distinguish themselves from the Stoics. For, a dogmatic Stoic believes that the sage's opinions are definitely true. Metrodorus and Philo, however, hold the truth of the sage's views only to be more likely than their falsehood and in this sense these views are only provisionally held. If the Academic sage of this type encounters an argument that has the force to persuade him of the opposite of a view that he has held so far, he will change his mind.

Now historically speaking, the Metrodorian-Philonian view of Academic scepticism carried the day - at least in the West. From late antiquity onwards scepticism was mostly identified with this specific form of Academic scepticism. This was mainly due to the influence of Cicero's Academica and of St. Augustine's Contra Academicos, itself heavily reliant on Cicero's work. ${ }^{12}$ When discussing this strand of scep-

11 For this translation see Brittain 2001, 73-128. For the following argument see Frede 1997 and Brittain 2001.

12 See Frede 1997, esp. $146 \mathrm{ff}$. This might also be the historical reason why, during the Renaissance, people on the whole did not distinguish between Pyrrhonian and Academic scepticism and used, as Schmitt 1972 has shown, the words "Academic" and "Pyrrhonian" synonymously. 
ticism in early modern philosophy, scholars usually refer to it, following Hume, as "mitigated scepticism". ${ }^{13}$

Limbrick identifies Academic scepticism with its mitigated form, and this is, I think, how she understands Sanchez's use of "probabile" in the passage referred to above from his commentary on Galen's $D e$ differentiis morborum (her third argument in favour of a Sanchezian Academic scepticism). This is why she claims that Sanchez possesses "a philosophical method, in the manner of the Academic sceptics, as a way of arriving at the criterion of truth which would allow for qualified assent to the objects of experience" (Limbrick 80). In this sense she also states that the Academic sceptics, and Sanchez following them, "advocated a system of methodological doubt which would free the human mind from the fetters of the past and enable the sceptical enquirer to re-establish knowledge on a firmer empirical basis" (Limbrick 88). This shows, I think, that Sanchez's alleged academic scepticism is, according to Limbrick, of the mitigated type.

On the basis of the passage from Sanchez's commentary on Galen's De differentiis morborum (Limbrick's third argument) we cannot decide, however, in which of the two ways discussed Sanchez uses the term "probabile". In order to decide this, we will have to turn to Sanchez's sceptical oeuvre, namely to his Quod nihil scitur. If Sanchez were an Academic sceptic of the alleged type, we would expect him to have a lot to say about the "probabile" in this work. We would also expect to find the method there that allowed Sanchez, according to Limbrick, to "reestablish knowledge on a firmer empirical basis."

Let us first consider the question of the method. We find four references to a book that Sanchez claimed to wish to write and whose topic is the methodus sciendi, the method of knowing. ${ }^{14}$ Unfortunately, however, there is no evidence that he ever actually wrote a book of that name, or one dealing with a method of knowing. No such book is extant and there is no reliable source testifying its existence. Thus, we can only speculate about its potential content on the basis of what we find in Quod nihil scitur. The most explicit reference to the method of knowing can be found in the last lines of Quod nihil scitur. There Sanchez

13 D. Hume, An Enquiry concerning Human Understanding, $\S \S 129-130$.

14 Quod nihil scitur, 11 (marginal note), 88 (marginal note), 90, and 100. I shall refer to the page numbers of the first edition of Quod nihil scitur. These page numbers can be found in the margins of both the Latin text and the English translation of the edition of Limbrick/Thomson. Unfortunately, Limbrick and Thomson do not render the marginal notes. 
states: "If you know anything, teach me. For I shall be very grateful to you. In the meantime, I prepare myself for the examination of things and I shall put forward in another book whether anything is known and [if anything is known] how, a book in which I shall expound, as far as human frailty allows, the method of knowing. Farewell." In this passage, Sanchez refers forward to the aforementioned book. He states his intention to expound in it the (or a) method of knowing. But it is clear that the exposition of such a method presupposes the settling of the question whether anything is known. In order to settle this question Sanchez goes on with his enquiry. Although Sanchez hopes to settle the question he does not claim that he has settled it. ${ }^{15}$ Neither does he claim that he is in possession of the method of knowing. Instead he promises that he will show the method of knowing if he has found out whether anything is known. For only then will he be able to know how anything is known. Consequently, we do not have the slightest idea as to what this method would have been like. In particular - and this is crucial for the present context - there is no evidence that Sanchez was to expound some kind of probabilism.

Let us now turn to the question of what Sanchez has to say about the probabile. He uses the term only three times in Quod nihil scitur. We find one occurrence on page 80 where he uses the word "probabile" to report what his opponents, the dogmatic Aristotelians, do when they try to prove something. He claims: "But, in proving all these things, what arguments do they not use? [...] Should false probabilia not suffice, they make use of statements that are true, but deplorable: that is to say, insults, invectives, defamatory libels, and abuse." Whatever Sanchez has in mind when he attributes to his opponents false probabilia, it has nothing to do with his own suspected probabilism. His own probabilism, if there were such a thing, would be a new method that his dogmatic opponents lack and this would be the reason why he attacks them. He wants, in this reading, to replace the old and rusty Aristotelian model of science with a new and 'sceptical' one. Thus, even if his opponents were probabilists this would not prove that Sanchez was a probabilist.

The second occurrence of "probabile", if given a probabilist interpretation, faces similar problems. On page 48 Sanchez discusses the manifold of the world in which everything is related to everything else. He then rhetorically asks: "Who knows this manifold exactly? No one does. They [the opponents] only say probabilia and nothing that they know for sure." Again, this does not help to establish any kind of probabilism on Sanchez's part. The opponents only say probabilia. What Sanchez thinks about the probabile remains open. But even if Sanchez did agree with his opponents about the probabile, it is unclear whether we should understand this agreement in the rad-

15 This squares nicely, as we shall see, with the kind of scepticism to which, if I am right, Sanchez adhered. 
ical Clitomachean sense, in the mitigated Metrodorian-Philonian sense or perhaps in a third sense. Thus the second passage is of no help either.

The third passage is more interesting. Sanchez seems to speak in propria persona ${ }^{16} \mathrm{He}$ discusses the senses and the mind and claims that while the senses are unreliable, the mind is even more unreliable. For the mind, he argues, depends on the senses and only adds to their mistakes. He considers what happens when the mind, after having detected that it has been deceived by the senses, tries to find the source of the mistake. One potential source is the medium through which the sense in question has perceived its object. Sanchez considers this: "[The mind] regards one or another medium as suspect. Concerning this latter it once again poses the question whether it is true or false. It is incapable of determining this, since it is above the senses. It acts probabiliter; and like this ad infinitum. There is no conclusion, no end to doubt" (67).

The context of this quotation is Sanchez's discussion of media. He has shown that - depending on the medium through which we perceive something - a thing can appear in different ways to us. If we see something through glass, for example, the thing will look different from the way it looks through air (63). In order to have a normal sense perception (i.e. a sense perception that represents the thing perceived in the way the thing is) certain criteria must be fulfilled. One of them is that the medium is such as to allow for normal sense perception. But now the mind can go one step further and ask what the conditions are that a medium has to fulfil in order to allow for normal sense perception. But how do we know that these conditions are the conditions that a medium has to fulfil in order to allow for normal sense perception? In order to answer this question we have to find the conditions that the conditions have to fulfil that the medium has to fulfil in order to allow for normal sense perception. We can go on like this ad infinitum.

Now it might strike the mind as persuasive that the medium is not such as to allow for normal sense perception. Or it might strike the mind as persuasive that a further condition is not fulfilled. But just as in the case discussed before the fact that something strikes the mind as persuasive does not imply that the mind's persuasion is probable and that the word "probabile" has to be understood in the mitigated sense. Sanchez does not claim that the mind has reasons to believe that the

16 This argument might also be purely dialectical. But if it is dialectical the third and last occurrence of "probabile" in Quod nihil scitur is of as little help as the first two. 
medium is trustworthy (or not). But in what sense does Sanchez use the term "probabile" here? Given the immediately following sentence, the mind does not seem to acquire knowledge by following what is more persuasive. Instead, it will never be in a position to know where the mistake has occurred (not even provisionally). For, "[t]here is no conclusion, no end to doubt" (ibid.).

To conclude this part of the argument, Sanchez uses the word "probabile" only three times in his sceptical writing. None of them, however, points to a Sanchezian probabilism. Furthermore, nowhere does he develop a systematic account of the notion of the probabile. And nowhere does he develop a method that would establish an empirical (or other) basis for (even if only provisional) knowledge. Thus, it seems very unlikely that Sanchez was an Academic sceptic in any probabilist sense. ${ }^{17}$

\section{II}

Was he, then, a Pyrrhonian sceptic? According to Popkin, the reception of the writings of Sextus Empiricus in the sixteenth century had a huge influence on Seventeenth Century Philosophy. ${ }^{18}$ In 1562 Henricus Stephanus published his Latin translation of Sextus' Outlines of Pyrrhonism. In 1569 it was republished, together with Hervetus' Latin translation of Against the Mathematicians. ${ }^{19}$ Both editions had a considerable influence on late Renaissance philosophy, as can be seen, for example, in the case of the perhaps most famous of Renaissance sceptics, Michel de Montaigne. ${ }^{20}$ Now Stephanus and Montaigne, like Sanchez, lived in Southern France. Moreover, Montaigne published his Essais in the year 1580, one year before Sanchez published his Quod nihil scitur. Thus, Sextus was both well known and available in Latin when and where Sanchez lived and it would be unsurprising to find Sanchez using Sextus and being influenced by him. There is, however, no refer-

17 A similar examination could be made for the word "probare" and with analogous results. Sanchez uses it for "to persuade" and systematically distinguishes it from "demonstrare" ("to prove"). His use does not indicate, however, any kind of probabilism.

18 This as well as Popkin's further claim that modern philosophy rose out of a "crise pyrrhonienne", kindled by the rediscovery of the writings of Sextus Empiricus in the $16^{\text {th }}$ century, are disputed. See Ayers 1998, 1007f., and Perler 2004.

19 For the history of the transmission of Sextus' text see Floridi 2002.

20 See Gray 1986 and Floridi 2002, 48 . 
ence to Sextus in Sanchez at all and most scholars agree that Sanchez did not know Sextus' writings.

One exception to this general consensus is de Carvalho. ${ }^{21} \mathrm{He}$ believes that Sanchez knew Sextus' writings because Sanchez used some of the modes or tropes of scepticism that play such a prominent role in Sextus. ${ }^{22}$ Sanchez indeed uses sceptical tropes in his arguments. ${ }^{23}$ This does not prove, however, that he knew Sextus' writings. For the tropes can also be found in the ninth book of Diogenes Laertius' Lives of eminent Philosophers. ${ }^{24}$ Since Sanchez refers to Diogenes' Lives in almost a dozen marginal notes, it is clear that he knew this text. It is reasonable to assume that he found the tropes there and we are not entitled to assume on the basis of his knowledge of the tropes that he knew Sextus' writings. Moreover, he usually refers to the Lives in the same marginal notes in which he refers to Plutarch's Adversus Colotem. Both book nine of the Lives and Plutarch's Adversus Colotem served him as points of reference for his scepticism. If he had known Sextus these marginal notes would have been the place to refer to him. The fact that he did not do so, might be seen as an indication that he did not know Sextus' writings.

The question whether Sanchez knew the writings of Sextus would need a detailed examination of Sanchez's arguments and their comparison with arguments in Sextus, Diogenes Laertius and other relevant sources. I will not undertake this examination in the present essay and leave this question open. Instead, I wish to study what Sanchez himself says about knowledge and thus try to find out systematically whether his scepticism is of the Pyrrhonian type. For an ignorance of Sextus does not imply, of course, that he did not know about Pyrrhonism, let alone that he was not a Pyrrhonian sceptic.

Sanchez begins his essay Quod nihil scitur with the following words: "Not even this one thing I know, namely that I know nothing." 25 Right from the beginning, Sanchez makes it clear how he does not want the title of his work to be understood. The title should not kindle hope in the reader that in this book he will find arguments that establish that nothing can be known. It is not the aim of the book to show, let alone to demonstrate, that nothing can be known. Instead, in beginning his book in this way, Sanchez distinguishes himself from another class of

21 De Carvalho 1955, xl.

${ }^{22}$ For a discussion of tropes in ancient scepticism see Annas/Barnes 1985 and Barnes 1990.

${ }^{23}$ For example, on 33, 39, 60 and $93 \mathrm{f}$.

24 Diogenes Laertius, Lives IX, $79 \mathrm{ff}$.

25 Cicero (Academica 1, 45) attributes this view to the Academic Arcesilaus and both Cicero (Academica 2, 73) and Diogenes Laertius (Lives IX, 58) attribute it to the Presocratic Metrodorus of Chios in whom Diogenes saw a precursor of Pyrrho of Elis whose teacher, Anaxarchus, was, according to Diogenes, Metrodorus' pupil. 
sceptics who claim that they know nothing and are firmly convinced that nothing can be known. One of those other sceptics is, for example, a character in Cicero's Academica, namely Catulus. Catulus forcefully (vehementer) assents to the claim that nothing can be known (Cicero, Academica 2, 148). Catulus also attributes this claim to Carneades, being aware of the fact that not everyone in the Academy agrees with this attribution. We have already seen in our discussion of the notion of the probabile that Carneades was interpreted in two different ways within the Academy. Catulus, as he is presented by Cicero, clearly follows the mitigated Metrodorian-Philonian line. As opposed to Catulus, Sanchez does not forcefully claim that nothing can be known. He does not even know whether he knows nothing. Thus we have found one more argument for the claim that Sanchez is not an Academic sceptic in this sense. He does not feel himself in a position to claim that he knows nothing. Sanchez's refraining from the claim that he knows nothing is, however, compatible with Pyrrhonism. The different attitude towards the sentence "nothing can be known" distinguishes, according to Sextus, Pyrrhonian from Academic scepticism (Sextus, Outlines I 226).

A further passage of importance can be found in Sanchez's address to the reader:

Yet I will not at all promise you the truth because I am ignorant of it - as of everything else. Nevertheless I will pursue it with all my power and you for your part shall pursue it [...]. Yet do not expect ever to capture it [...] let the chase suffice for you, as it does for myself. For this is my aim and my end - an aim and end that you too must seek. (v)

Compare this passage with what Sextus claims about Pyrrhonian scepticism. While the dogmatic philosophers, according to Sextus, believe that they have discovered the truth and while the Academic philosophers claim that it cannot be discovered, the Pyrrhonian sceptic continues with his search (cf. Outlines I, 3).

Sanchez has a similar tripartition of philosophers in mind. The dogmatic philosophers of his day are scholastic Aristotelians. One of the aims of Quod nihil scitur consists in attacking their theory of knowledge and its most important tool, namely syllogistic. In destroying their theory of knowledge, Sanchez tries to show that the Aristotelians' claim to have discovered the truth is vain. Neither does Sanchez, however, as we have learnt from the passage discussed above, claim that the truth cannot be discovered. In this way he distinguishes his scepticism from the mitigated Academic scepticism. Instead he, like the Pyrrhonian sceptics, goes on inquiring. 
I wish to note in passing that also Diogenes Laertius attributes this attitude to the Pyrrhonians:

All these were called Pyrrhonians after the name of their master, but also [...] Sceptics, $[\ldots]$ and even Seekers, from their principles, if we may call them such Seekers because they were ever seeking truth, Sceptics [or enquirers] because they were always looking for a solution and never finding one [...] (Lives IX, 69f.). ${ }^{26}$

Here, again, a Sanchezian Pyrrhonism is compatible with the possibility that Sanchez did not know Sextus' writings.

So far, it seems to me, Sanchez's scepticism is well compatible with Pyrrhonism. ${ }^{27}$ There is, however, at least one thing that distinguishes Sanchez's scepticism from that of the ancient Pyrrhonists. Sextus explains that men of talent were perturbed by the contradictions in things and in doubt as to which of the alternatives they ought to accept (Outlines I, 12). They became dogmatic in the hope of attaining tranquillity in this way (ibid.). Instead of achieving tranquillity, however, they got even more perturbed (Outlines I, 27). The Pyrrhonists show to such a person that for every dogmatic argument whose conclusion this person might be inclined to accept there exists an equally strong counter-argument. In this way dogmatic arguments lose their grip on the person and he or she is no longer perturbed by dogmatism, and tranquillity in dogmatic questions follows (Outlines I 26-27). ${ }^{28}$ To put it differently: a person, infected by dogmatism, gets treated and cured by a Pyrrhonist. Thus, there is a crucial practical side to Pyrrhonism. The ancient Pyrrhonists do not only refute their opponents' arguments on a theoretical level. Instead their sceptic activity plays an important role in a sceptic's life and is thus not only theoretical but also practical.

In Sanchez's work, however, there is no mention of tranquillity and he nowhere considers scepticism as something that achieves anything beyond the destruction of dogmatic claims and arguments. Nowhere in his work does he claim that his scepticism provided him with some kind

${ }^{26}$ See also Diogenes Laertius, Lives IX, 74: "The sceptics, then, were constantly engaged in overthrowing the dogmas of all schools, but enuntiated none themselves; and though they would go so far as to bring forward and expound the dogmas of the others, they themselves laid down nothing definitely, not even the laying down of nothing" (Bury's translation, my emphasis).

27 It is as well compatible with Clitomachean Academic scepticism. If it is true that Pyrrhonism is a further development of Clitomachean Academic scepticism (in deliberate opposition to the mitigated scepticism of Metrodorus and Philo) then this is no coincidence (for this claim see Photius 212 and Frede 1997, 146).

${ }^{28}$ For tranquillity see Striker 1996b. 
of tranquillity. Was his scepticism then detached from life and a purely theoretical affair? If so, he would fit the picture that we find in Descartes. Descartes saw, as Burnyeat points out, the concern for practical affairs of life as something that, while being crucial for the ancient sceptics, was of no concern to the modern ones. ${ }^{29}$

At first sight Sanchez's scepticism also seems to be restricted to theoretical questions. He does not, for example, discuss ethical questions. The reason for this, perhaps, can partly be found in Sanchez's religious conviction. Sanchez was a Christian of the Catholic conviction, teaching in the Catholic stronghold of Toulouse. He explicitly claims that revelation is true and opposes it to the beliefs of the philosophers (42). ${ }^{30}$ If faith plays such a crucial role in one's life as it did in his, it is clear that scepticism is not the answer to all practical questions. The answer to moral questions, for example, will be crucially influenced by one's religious conviction. And it is also likely that Sanchez, unlike the ancient Pyrrhonists, held strong views about the aim of one's life.

On the other hand, this is not sufficient to show that his scepticism was purely theoretical. In order further to investigate the question of the relationship between his scepticism and his life, we have to remind ourselves that Sanchez was a medical doctor at the Hôtel-Dieu, the hospital of Toulouse, for thirty years. How can a sceptic be a medical doctor? Now, one possibility is indeed that he considered his scepticism as purely theoretical and that he based his medical practice in spite of his theoretical scepticism on dogmatic medical theories. There is, however, also a further possibility, namely the possibility that Sanchez had certain views about medical praxis that allowed him as a sceptic to practice medicine. I shall argue that Sanchez indeed held such views and that he had inherited them from the ancient medical school of empiricism.

29 Burnyeat 1982, 39f. with reference to Descartes (Haldane/Ross I, 206; II 206, $335)$.

${ }^{30} \mathrm{He}$ also ends several of his treatises with a formula in praise of God and the Virgin Mary (namely De longitudine et brevitate vitae, In librum Aristotelis physiognomicon commentarius and De divinatione per somnum). Moreover, two of his sons became Catholic priests. 


\section{III}

Ancient empiricism did away with theories in any dogmatic sense and was - at least from some point onwards - closely related to Pyrrhonian scepticism. ${ }^{31}$ We have historical evidence for this close relationship. Thus, Sextus Empiricus who is nowadays perhaps the most famous proponent of ancient Pyrrhonism, was, as his name suggests, an empirical doctor. But also Menodotus and Theodas were representatives of both empiricism and Pyrrhonian scepticism. ${ }^{32}$

Empiricist doctors held the view that everything that one needs to know in treating patients is a matter of experience. There is no need, according to them, for medical theories and thus there is no need for the postulation of entities - such as atoms or elements - that can only be grasped by reason. The empiricists also opposed the rationalists' use of formal inference and in this way also the rationalists' use of logic. Instead, so they thought, experience was sufficient. According to Galen's Outline of Empiricism (Subfiguratio empirica), one of our main sources for ancient empiricism, the empiricists mean by experience the knowledge, which is based on one's own perception (Galen, Outline, 44 Deichgräber). ${ }^{33}$ Two further methods were important for the empiricists, namely history and transition to the similar. As Galen explains:

By 'history', they mean the report of one's own perception and by 'transition to the similar', a method which leads to practical experience which is based on the similarity with what one already knows by experience (ibid. 49).

Thus a medical doctor acquires experience in relying on what he himself perceives, on the (carefully checked) reports of other people and on the transition from cases that he is familiar with to cases which are similar to those cases.

Several questions might occur at this point. Firstly, how do they justify their three methods without, in so doing, becoming dogmatic? Secondly, is it possible to act as a medical doctor without relying on reason at all, i.e. solely relying on sense perception? Thirdly, as far as sense perception is concerned, are they not dogmatically claiming or implying

31 For ancient empiricism see Deichgräber 1965 and Frede 1987. For the following sketch I will rely on the latter.

32 For the close relation of ancient empiricism to scepticism see already Zeller 51923, $18 \mathrm{ff}$. and Brochard 21932, $27 \mathrm{ff}$. For a more recent discussion see Hankinson $1995,225-236$.

33 For Galen's Outline of Empiricism I shall refer to Deichgräber's 1965 edition. 
that the senses are reliable? Answering these questions is not only important for our understanding of ancient empiricism but it might also help us to understand how empiricism fits Sanchez's scepticism.

To the first question. The empiricists would not try to justify their method in any dogmatic sense. Instead, they would claim that experience recommends these three methods to them. It is important to note that all three methods heavily rely on our ordinary life experience. People in their ordinary lives generally have trust in things that they have seen with their own eyes (or heard with their own ears etc.). They also trust reports that they hear from other people if they believe that the people reporting them are trustworthy. Ordinary life experience further suggests that, if something works in one case, we should try it in similar cases. The empiricists would not provide us with any theoretical reasons for believing in these three methods. Nor would they claim that these three are the only possible methods. The empiricists do not believe themselves to know that these methods are certain or even probable. Thus they do not justify their use of these methods. They only follow the practice of ordinary life because they have experienced that they can practise medicine in this way quite successfully and certainly at least as successfully as the rationalists who believe their practice is based on theory.

To the second question. The empiricists allow for the use of reason to the extent that people in ordinary life use reason. They have no qualms accepting that people in ordinary life at least sometimes think and take decisions. But as soon as reason goes beyond the world of ordinary experience and tries to find truths that lie beyond it, the empiricist will observe that, at least in every single case hitherto investigated, it has been revealed to be inadequate.

To the third question. In the same way in which they accept reasoning, the ancient empiricists accept sense perception. They do not possess a theory of sense perception and in this sense they do not know when and why sense perception goes wrong. But generally they rely on sense perception in the way in which an ordinary person relies on sense perception. Experience shows that most of the time it seems to work fine.

This is only a very rough sketch of ancient empiricism. But even in this sketch we can see, I hope, its close affinity to Pyrrhonism. Let us now return to Sanchez and ask whether we have evidence that speaks in favour of a Sanchezian empiricism in the ancient sense. It seems to me that there is. As far as ordinary experience is concerned, Sanchez has no doubts. He does not doubt, for example, that the farmer can distinguish his donkey from his neighbour's ox (67). Like the empiricists, however, he doubts the existence of theoretical entities that we cannot encounter in our daily lives. Thus he asks:

For who could understand non-existent things? Thence come Democritus' Atoms, Plato's Ideas, Pythagoras' Numbers, and Aristotle's Universals [...]. In this way they [the dogmatic philosophers] entrap the unwary claiming to have discovered unknown things and the secrets of Nature. (iv) 
Although, as we have already seen, Sanchez claims that our sense perception and our reason often go astray, this critique is primarily a problem for a theoretical approach that is based on sense perception and reason. The usefulness of senses and reason, however, for daily life is not being questioned. Moreover, sense perception and reason are also useful to understand that the claims of the Aristotelians are not convincing. In the address to the reader Sanchez states: "I wish to address myself to those who - not bound by an oath of fidelity to any master's words - assess the facts for themselves, under the guidance of sense-perception and reason" (iv).

How important experience is for Sanchez can also clearly be seen in another passage. He considers the case of a sailor who has learnt navigation from books, and is sitting in the kitchen imagining rocks and capes, Scyllas and Charybdises, navigating his ship superbly across the table. But if he were to go aboard a ship to steer it he would dash on those very rocks and capes that he was previously so well acquainted with (70). In the same context Sanchez claims that a physician heals a disease better if he himself has previously experienced it. In order to be able to judge something, Sanchez concludes, one has to be acquainted with it. Experience is the best means to get acquainted with it. In the same vein Sanchez states:

Much experience, then, makes a man both learned and wise. Hence it comes about that old men are more learned, at least in terms of experience, and thus better adapted for the conduct of human affairs than the young [...]. If they possess good judgement as well, the administration of the state can fittingly be entrusted to them. (92)

In specific fields - such as agriculture, navigation and commerce - we have to trust the experts because the experts are acquainted with and experienced in their field whilst the philosophers are neither (cf. 98). ${ }^{34}$ The same, no doubt, is true in medicine.

We can see from these passages that Sanchez's scepticism and ancient empiricism are well compatible. The similarities are striking. As it seemed to the ancient empiricists that - for practical purposes - we have to rely on experience and that - all in all - experience has proved to be a successful guide for the conduct of human affairs - so does it seem to Sanchez. Sanchez also professes the view that certain people are experienced in certain fields in such a way that they have acquired some kind of expertise, which distinguishes them from laymen. Although these experts can go about their business usually quite successfully, they do not

${ }^{34}$ Sanchez makes also room for the second empiricist method, namely history (98). In Quod nihil scitur there is no discussion of transition from the similar to the similar. Given the kind of writing it is, namely basically a sceptic critique of dogmatic Aristotelianism, this is perhaps not surprising. 
possess knowledge in any dogmatic sense. There is no theory that backs their praxis and, according to Sanchez, so far no one has found a theory that would be able to do so.

It is not by chance that Sanchez's scepticism is so similar to ancient empiricism. Instead, he was acquainted with it. Galen is one of our main sources of ancient empiricism and as a medical doctor in the $16^{\text {th }}$ century, Sanchez knew his Galen well. ${ }^{35}$ Galen was, after all, still the most important and most widely read authority at the faculties of medicine all over Europe. True, the Galenism taught there was - all in all - of a rather dogmatic kind and closely related to Aristotelianism. ${ }^{36}$ But his omnipresence also made him readily available as a source for empiricism. Of the four most important Galenic sources on empiricism, Sanchez was familiar with at least two, namely with On the Therapeutic Method (De methodo medendi) and with the Outline of Empiricism. While he does not explicitly refer to the former in Quod nihil scitur, he does so to the latter, namely in a marginal note on $91 .{ }^{37}$ Sanchez refers to this treatise in a passage where he tells a story that he has found there about a man who suffered from elephantiasis. Some harvesters (in Sanchez's version of the story) believed that they would do a good deed if they gave to this poor man a drink of wine to which the poison of a viper had been added. Whilst they thought in this way they would remove him from life, the opposite happened. The person was delivered from his dreadful disease (cf. Quod nihil scitur 91 f.; Galen, Outline $75 \mathrm{ff}$. Deichgräber). Sanchez uses this example in a context in which he tries to show that experience sometimes shows the opposite of what one would reasonably expect. But for the present purpose, this is not important. Instead, it is important that we are now in a position to ascertain the claim that Sanchez was familiar with ancient empiricism and that we have found a textual basis for the affinity of his scepticism with ancient empiricism.

35 Galen's relevant texts are available in English: On the Sects for Beginners, On Medical Experience and An Outline of Empiricism in Frede 1985. The fourth relevant text, the first two books of On the Therapeutic Method, can be found in Hankinson 1991.

36 For this see Gilbert 1960, Mugnai Carrara 1983. and Schmitt 1985.

37 The reference to De methodo medendi can be found in Sanchez's De longitudine et brevitate vitae, 75, 78 and 79 de Carvalho. 


\section{IV}

To conclude, Sanchez was not an Academic sceptic. He opposed the mitigated scepticism that we find in Cicero and in St. Augustine and explicitly rejected it. In keeping with this, we were unable to find any kind of probabilism in Sanchez. Moreover, Sanchez did not claim that we come closer to the truth in applying some method of knowing and he did not claim that we possess knowledge of a non-dogmatic, modest and provisional kind. Whilst the mitigated Academic sceptics were convinced that we cannot have knowledge of any robust and dogmatic sort, Sanchez was not even certain about this. It rather seemed to him that our search for the truth must go on. In all this, Sanchez followed Pyrrhonian scepticism (whether he was familiar with the writings of its most prominent exponent or not). But, what is more, the close affinity of ancient Pyrrhonism and ancient empiricism also finds a modern equivalent in Sanchez. For him, scepticism was not only of theoretical concern. Like the ancient empiricists Sanchez believed in the huge importance of experience for the conduct of life and for such practical fields as agriculture, navigation, and - not least - medicine. Whether, however, experience would lead us nearer to the truth and provide us with a fundament of knowledge remained, for Sanchez, doubtful. ${ }^{38}$

Annas, J./Barnes, J. 1985. The Modes of Scepticism. Cambridge.

Ayers, M. 1998. "Theories of Knowledge and Belief". In Garber, D./Ayers, M. (eds.), The Cambridge History of Seventeenth Century Philosophy. Cambridge, vol. II, 1003-1061.

Barnes, J. 1990. The Toils of Scepticism. Cambridge.

Brittain, Ch. 2001. Philo of Larissa. The Last of the Academic Sceptics. Oxford. Brochard, V. 21932. Les Sceptiques Grecs. Paris.

Burnyeat, M. F. 1982. "Idealism and Greek Philosophy: what Descartes saw and Berkeley missed". The Philosophical Review 91, 3-40.

38 This paper is one of the results of a project on Sceptical Arguments in Late Medieval and Early Modern Philosophy, generously enabled by the Swiss National Foundation, another result being a new edition and German translation of Quod nihil scitur that has been undertaken by Kaspar Howald, Sergei Mariev and myself (in print). I am very grateful to Michael Frede for his helpful comments on an earlier draft of this paper, to Kaspar Howald for many a valuable discussion about Sanchez, to the directors of the project, Therese Fuhrer and Dominik Perler, as well as to Sergei Mariev, Peter Turner, Markus Wild, and Roland Wittwer. 
Burnyeat, M. F./Frede, M. (eds.) 1997. The Original Sceptics: A Controversy. Indianapolis.

de Carvalho, J. (ed.) 1955. Francisco Sanches. Opera Philosophica. Coimbra.

Deichgräber, K. (ed.) 1965. Die griechische Empirikerschule. Berlin/Zurich.

Floridi, L. 2002. Sextus Empiricus. The Transmission and Recovery of Pyrrhonism. Oxford.

Frede, M. (ed.) 1985. Galen. Three Treatises on the Nature of Science. Indianapolis.

Frede, M. 1987. "The Ancient Empiricists". In his Essays on Ancient Philosophy. Oxford, 243-260.

-. 1997. "The Sceptic's two kinds of Assent". In Burnyeat/Frede 1997, 127-151.

Gilbert, N. W. 1960. Renaissance Concepts of Method. New York/London.

Gray, F. 1986. "Montaigne's Pyrrhonism". In La Charité, R. C. (ed.), O un Amy! Essays on Montaigne in Honor of Donald M. Frame. Lincoln, 118-36.

Hankinson, R. J. (ed.) 1991. Galen on the Therapeutic Method. Oxford.

Hankinson, R. J. 1995. The Sceptics. London/New York.

Jolly, C. (ed.) 1990. G. Naudé. Advis pour dresser une bibliothèque. Paris.

Limbrick, E./Thomson, D. F. S. (eds.) 1988. Francisco Sanches. That nothing is known. Cambridge/New York.

Mugnai Carrara, D. 1983. "Una Polemica Umanistico-Scolastica circa l'Interpretazione delle tre Dottrine Ordinate di Galeno". Annali dell'Istituto e Museo della Scienza di Firenze 8, 31-57.

Perler, D. 2004. "Was there a 'Pyrrhonian Crisis' in Early Modern Philosophy?". Archiv für Geschichte der Philosophie 86, 209-220.

Popkin, R. H. ${ }^{32003}$. The History of Scepticism from Savanarola to Bayle. New York.

Schmitt, C. B. 1972. Cicero Scepticus: A Study of the 'Academica' in the Renaissance. The Hague.

-. 1985. "Aristotle among the Physicians". In Wear, A.; French, R. K.; Lonie, I. M. (eds.), The Medical Renaissance of the Sixteenth Century. Cambridge, 1-15.

Striker, G. 1996a. "On the Difference between the Pyrrhonists and the Academics". In her Essays on Hellenistic Epistemology and Ethics. Cambridge, 135-149 (originally in Phronesis 26 (1981) 153-71).

-. 1996b. "Ataraxia: Happiness as Tranquillity". In her Essays on Hellenistic Epistemology and Ethics. Cambridge, 183-208 (originally in The Monist 72 (1990) 97-110).

Zeller, E. 51923. Die Philosophie der Griechen in ihrer geschichtlichen Entwicklung. III.2.2. Leipzig. 